\title{
A proposed simple method for determining the outflow of ciliates from the reticulo-rumen
}

\section{T. Michalowski}

The Kielanowski Institute of Animal Physiology and Nutrition. Polish Academy of Sciences 05-110 Jablonna near Warsaw, Poland

(Reccived 14 April 1997; accepted 14 January 1998)

\begin{abstract}
ABSTR $\Lambda C T$
Two adult male sheep were used to determine the outflow of protozoa from the reticulo-rumen. The outflow of ciliates was calculated on the basis of their concentration in reticular digesta and volume of effluent leaving the reticulo-rumen. The concentration of ciliates from the genus Entodinium and Diplodinium in reticulum was by $33-63 \%$ and $32-73 \%$ lower than in the rumen. The concentration of Holotricha varied between 55.7 and $126.8 \%$ of the ruminal density. No differences were found between the concentration of protozoa in reticular digesta taken at the contraction and resting phases of the reticulum. The number of ciliates lcaving the reticulo-rumen per day equaled $66-177 \%$ of their number in the rumen. and the apparent residence time of protozoa varied between 13.8 and $36.6 \mathrm{~h}$. It was longest in the case of ciliates from the genus Dipolodinium and the shortest in the case of Isotricha. A technique for the collection of reticular digesta at the contraction and resting phases of the reticulum is described.
\end{abstract}

KEY WORDS: rumen ciliates, outflow, residence time

\section{INTRODUCTION}

The forestomachs of ruminants are inhabited by numerous bacteria, fungi and protozoa. The protozoa are selectively retained in the rumen (Michałowski et al., 1986) but part of their population passes down from the reticulo-rumen to the omasum and then to the abomasum and duodenum. The outflow of protozoa from the 
rumen has been measured indirectly, i.e as flow of protozoal protein at the duodenum (Harrison et al., 1979; Steinhour et al., 1982; Whitelaw et al., 1984; Cockburn and Williams, 1984; John and Ulyatt, 1984; Meyer et al., 1986) and by a more direct method, i.e. by counting ciliates in omasal liquid taken from omasum (Weller and Pilgrim, 1974; Punia and Leibholz, 1994) or in omasal effluent (Michałowski et al., 1986). No satisfactory method has, however, been developed yet.

On the other hand it has been shown that the concentration of ciliates in omasal influent and in reticular digesta are almost the same (Harmeyer and Michałowski, 1991). It was also found in the same study that only reticular contents passed down to the omasum and that inflow to omasum was observed only during the second phase of contraction of the reticulum. If this is the case the concentration of ciliates in the reticulum could be used for calculation the number of protozoa leaving the reticulo-rumen over the day. The data cited suggest also that the samples taken at the contraction of reticulum would be the best for this purpose.

The aim of the present study was to determine the daily outflow of protozoa from the reticulo rumen on the basis of their concentration in reticular digesta and compare the obtained results with the data of other authors who measured the outflow of ciliates to lower gut of ruminants.

\section{MATERIAL AND METHODS}

\section{Animals and feeds}

Two adult male sheep ( $\mathrm{L}$ and $\mathrm{R}$ ) weighing 77 and $85 \mathrm{~kg}$ and fitted with $100 \mathrm{~mm}$ permanent rumen cannulas were used. The animals were kept in separate pens and given $300 \mathrm{~g}$ pelleted concentrate $(15.5 \%$ protein) and $700 \mathrm{~g}$ hay at $8 \mathrm{a} . \mathrm{m}$. and 4 p.m. Water was available all the time.

\section{Experimental procedure}

A 2 weeks adaptation period of animals to the food and feeding frequency was allowed before any collection of the samples of rumen and reticular digesta was started.

The samples of reticular digesta were taken via rumen cannula with the use of plastic tube of $10 \mathrm{~mm} \mathrm{ID} \mathrm{and} 500 \mathrm{~mm}$ in length. The tube was fitted with a tight rubber piston (Figure 1). A small balloon of an apparatus for recording contraction of the reticulum was fixed to the tube near its end and introduced into the reticulum during the sampling. The samples of reticular digesta were taken when the second phase of contraction of the reticulum wall had begun or during the resting phase. The samples were taken by suction made by pulling the piston to the opposite end of 


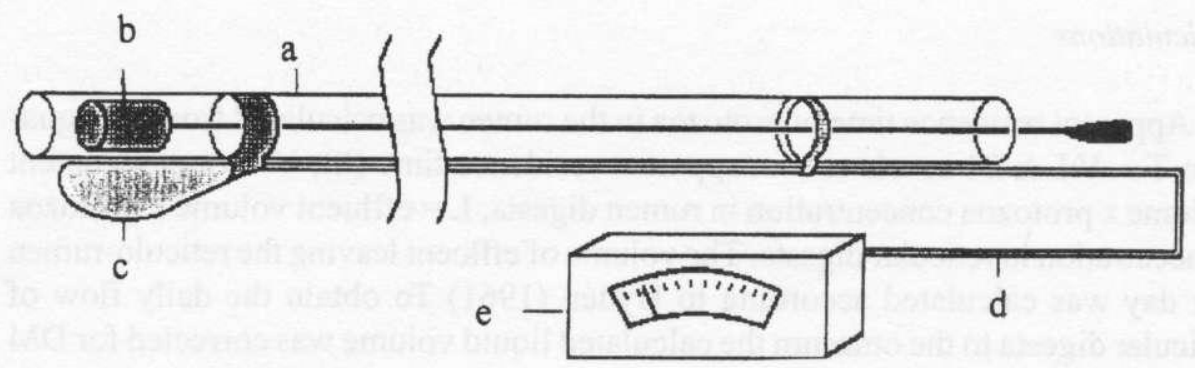

Figure 1. Device construction for collection of the reticular digesta via rumen cannula. a - collecting tube; $\mathrm{b}$ - rubber piston; $\mathrm{c}$ - ballon; $\mathrm{d}$ - connecting tube; $\mathrm{e}$ - recording apparatus

the collecting tube. The tube was then taken out and the sampled digesta was poured to a beaker. It was subsampled for protozoa counts $(5 \mathrm{~g})$ and for dry matter (DM) determination (the remaining part of the sampled material).

Rumen content (about $500 \mathrm{~g}$ ) was taken from different places in the rumen. The sampled material was thoroughly mixed, subsampled for protozoa counts $(2 \times 5 \mathrm{~g})$ and returned immediately to the rumen. The collection of rumen content was made immediately after sampling of reticular digesta. Both types of the material was collected at 2, 4, 6 and $8 \mathrm{~h}$ after morning feeding. The sampling was repeated four times on four different days.

The pool size of digesta was measured by removing and weighing all the rumen contents. The removed digesta was thoroughly mixed, subsampled for DM determination $(20-30 \mathrm{~g})$ and returned immediately to the rumen. The procedure was repeated four times, but no more than 2 times a week.

The volume of liquid leaving the reticulo-rumen was measured with the use of CrEDTA. A solution of marker $(60 \mathrm{ml})$ containing $750 \mathrm{mg} \mathrm{Cr}$ was introduced into the rumen at 8 a.m. and samples of rumen fluid $(20 \mathrm{ml})$ were taken at, 1, 2, 3, 4, 6, $8,10,14,20$ and $24 \mathrm{~h}$ thereafter. The collected samples were centrifuged at $20.000 \mathrm{~g}$ for 15 min and supernatant was used for $\mathrm{Cr}$ determination.

The experiment was repeated three times.

\section{Analyses}

Samples for protozoa counting, fixed in $4 \%$ formaldehyde solution $(1: 1 \mathrm{w} / \mathrm{v})$ were analyzed under light microscope. Entodinia were counted in a Fuchs-Rosenthal chamber while other ciliates by the method described earlier (Michałowski, 1975). The protozoa were identified according to Dogiel (1927) and Grain (1966). Dry matter was determined by drying the samples at $95^{\circ} \mathrm{C}$ for $48 \mathrm{~h}$. Cr was estimated by atomic absorption spectrometry as described by Michałowski et al. (1986). 


\section{Calculations}

Apparent residence time of protozoa in the rumen was calculated from the equation $\mathrm{T}=\mathrm{V}: \mathrm{L} \times 24 \mathrm{~h}$; where $\mathrm{T}=$ apparent residence time $(\mathrm{h}), \mathrm{V}=$ rumen content volume $\mathrm{x}$ protozoa concentration in rumen digesta, $\mathrm{L}=$ effluent volume $\mathrm{x}$ protozoa concentration in reticular digesta. The volume of effluent leaving the reticulo-rumen per day was calculated according to Hydén (1961) To obtain the daily flow of reticular digesta to the omasum the calculated liquid volume was corrected for DM content of reticular digesta.

All of the statistical calculations were made according to Ruszczyc (1970).

\section{RESULTS}

The weight of the digesta in the rumen of sheep varied between 12.1 and $17.1 \mathrm{~kg}$ and the volume of the effluent leaving the reticulo-rumen was 20.2-33.4 1/d. Mean values are given in Table 1. The concentration of ciliates in the rumen and reticulum of sheep "L" and "R" is presented in Tables 2 and 3, respectively. The ,Entodinium group" composed of many species of which the most numerous were Entodinium simplex, Entodinium caudatum and Entodinium longinucleatum. Anoplodinium denticulatum, Diploplastron affine, Polyplastron multivesiculatum and Ostracodinium obtusum formed the Diplodinium group, while Isotrich a prostoma, Isotricha intestinalis and Dasytricha ruminantium the „Holotricha group”. Very large variations in the number of Diplodinium and Holotricha were observed during the sampling period. No Diplodinia other than Polyplastron multivesiculatum were found in the rumen of sheep "L" on the first sampling day and no more than 160 cells/g during the second collection. The concentration of ciliates from the genus Diplodinium in the rumen of sheep " $\mathrm{R}$ " increased during the collection period from 1400 to over 28000 per gram. On the other hand, the number of Holotricha not exceeded 500 cells/g during the second collection day while the highest concentra-

TABLE 1

Some reticulo-rumen parameters of sheep

\begin{tabular}{lrr}
\hline & \multicolumn{2}{c}{ Sheep } \\
\cline { 2 - 3 } Item & \multicolumn{1}{c}{$\mathrm{L}$} & \multicolumn{1}{c}{$\mathrm{R}$} \\
\hline Rumen content volume, $\mathrm{kg}$ & $15.1 \pm 1.18$ & $13.0 \pm 0.75$ \\
Rumen content DM, \% & $8.5 \pm 0.62$ & $9.8 \pm 0.68$ \\
Effluent volume $\mathrm{kg} / \mathrm{d}$ & $28.6 \pm 3.36$ & $22.5 \pm 1.88$ \\
Effluent DM, \% & $3.7 \pm 0.45$ & $3.5 \pm 0.67$ \\
Rumen content, $\mathrm{pH}$ & $6.2 \pm 0.21$ & $5.8 \pm 0.33$ \\
Reticular content, $\mathrm{pH}$ & $6.5 \pm 0.14$ & $6.4 \pm 0.16$ \\
\hline
\end{tabular}


TABLE 2

The concentration of ciliates in the rumen $\left(\times 10^{3} / \mathrm{g}\right)$ and reticular digesta ( $\%$ ruminal concentration) of sheep" $L$ " during the contraction and resting phases of reticulum and at different time after feeding (h)

\begin{tabular}{lrrrrrr}
\hline \multirow{2}{*}{ Time } & \multicolumn{3}{c}{ Rumen } & & \multicolumn{3}{c}{ Reticulum } \\
\cline { 2 - 3 } \cline { 5 - 6 } after feedig & Number & SD & A & B & SD \\
\hline 2 & 522.4 & 154.54 & 63.4 & 64.8 & 11.49 \\
4 & 547.8 & 161.71 & 63.4 & 62.8 & 10.37 \\
6 & 539.9 & 135.74 & 61.4 & 63.2 & 7.89 \\
8 & 619.6 & 133.50 & 67.0 & 62.7 & 7.41 \\
& & & Diplodinium & & \\
2 & 2.7 & 2.63 & 45.7 & 35.0 & 7.06 \\
4 & 2.8 & 1.75 & 60.4 & 51.7 & 18.49 \\
6 & 4.2 & 3.23 & 29.2 & 27.1 & 6.44 \\
8 & 3.4 & 2.15 & 68.4 & 58.5 & 23.31 \\
& & & & Holotricha & & \\
2 & 12.5 & 8.24 & 80.0 & 58.3 & 25.51 \\
4 & 5.2 & 3.36 & 93.7 & 105.8 & 48.86 \\
6 & 3.5 & 2.47 & 126.8 & 122.0 & 36.98 \\
8 & 5.0 & 3.76 & 78.4 & 59.9 & 14.16 \\
\hline
\end{tabular}

A - contraction phase

$\mathrm{B}$ - resting phase

TABLE 3

The concentration of ciliates in the rumen $\left(\mathrm{x}^{1} 0^{3} / \mathrm{g}\right)$ and reticular digesta $(\%$ ruminal concentration) of sheep " $R$ ' during the contraction and resting phases of reticulum and at different time after feeding (h)

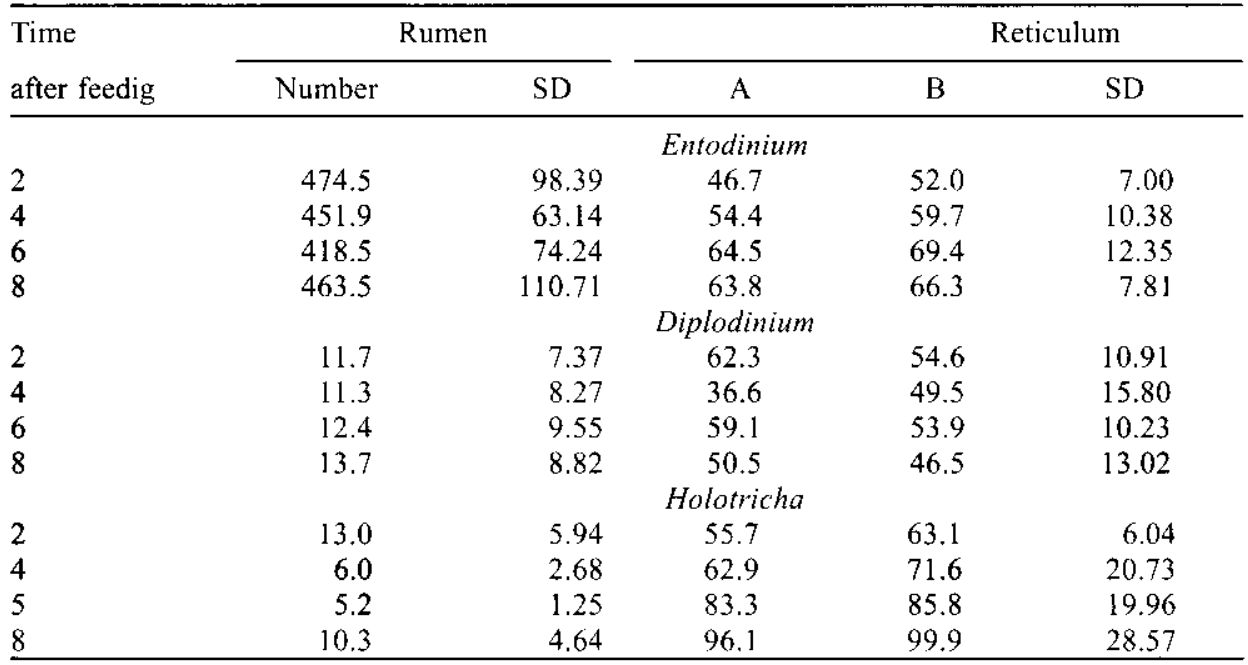

A - contraction phase

$\mathrm{B}$ - resting phase 
tion was over $22000 / \mathrm{g}$. Due to the mentioned variations the standard deviations were commensurately high. Regardless of the day to day variations, the concentrations of Entodinium and Diplodinium in the reticulum were by about 33-63\% and $32-73 \%$ lower, respectively as compared with their densities in the rumen. The higher concentration of Holotricha in the rumen was noted only 2 and 4 (sheep „L”) or 2 and 8 (sheep „R”) h after morning feeding. No significant differences were found between the concentration of ciliates in the reticulum contents taken at the contraction and resting phase. The densities of particular populations tended, however, to be, in majority of cases, higher in the samples taken at contraction. Of the Diplodinium and Holotricha the ciliates Polyplastron multivesiculatum and Dasytricha ruminantium were counted separately. The concentration of Polyplastron multivesiculatum in the rumen of sheep "L" varied from 360 to 3400 and in the reticulum from 160 to $2080 / \mathrm{g}$. The respective concentration in sheep "R" was $800-4480$ and $240-2160 / \mathrm{g}$. The population density of Dasytricha ruminantium in the rumen and reticulum of sheep "L" and "R" were 1700-20500 and 1800-10800, and $1700-17100$ and $1400-12200 / \mathrm{g}$, respectively.

Total number of ciliates in the rumen of sheep " $\mathrm{L}$ " as well as outflow rate and apparent residence time of the different groups of protozoa are presented in Table 4. The number of ciliates leaving the reticulo-rumen during a day was equal to $66-174.2 \%$ of their number in the rumen. According to this the apparent residence time varied from 14.7 to $36.6 \mathrm{~h}$. The residence time of Entodinium was similar regardless of the calculation basis. The residence time of other populations tended to be longer when it was calculated on the basis of concentration of protozoa in the samples taken at the resting phase of the reticulum.

A significant difference, however, was found in the case of "other Diplodinia" and "Dasytricha ruminantium" only.

The number of ciliates passing down from the reticulum of sheep " $\mathrm{R}$ " varied from 77 to over $177 \%$ of their number in the rumen. The smallest outflow was noted

TABLE 4

Total number (x 107/rumen), outflow rate (\% mean ruminal number/d) and apparent residence time $(\mathrm{h})$ of ciliates in reticulo-rumen of sheep „L". Outflow rate and residence time were calculated on the basis of ciliate number in the raticular digesta during contraction (A) and resting (B) phases of reticulum

\begin{tabular}{|c|c|c|c|c|c|c|c|c|}
\hline \multirow[t]{2}{*}{ Protozoa group } & \multicolumn{2}{|c|}{ Ciliates } & \multicolumn{3}{|c|}{ Outflow rate } & \multicolumn{3}{|c|}{ Residence time } \\
\hline & Number & SD & A & B & SD & A & B & SD \\
\hline Entodinium sp. & 838.3 & 212.58 & 118.6 & 119.3 & 13.80 & 20.5 & 20.4 & 3.20 \\
\hline Polypl. multivesiculatum & 3.5 & 0.58 & 102.8 & 96.6 & 21.92 & 23.8 & 27.2 & 6.56 \\
\hline „other Diplodinia" & 4.0 & 1.58 & 86.1 & 66.0 & 13.42 & 28.4 & 36.6 & 5.31 \\
\hline Isotricha $\mathrm{sp}$. & 1.2 & 0.11 & 143.6 & 116.7 & 47.59 & 18.8 & 23.5 & 7.80 \\
\hline Dasytricha ruminantium & 11.7 & 4.27 & 174.2 & 142.0 & 68.61 & 14.7 & 21.6 & 6.16 \\
\hline
\end{tabular}


TABLE 5

Total number ( $10^{7} /$ rumen), outflow rate ( $\%$ mean ruminal number/d) and apparent residence time (h) of ciliates in reticulo-rumen of sheep ,R”. Outflow rate and residence time were calculated on the basis of ciliate number in the reticular digesta during contraction $(A)$ and resting $(B)$ phases of reticulum

\begin{tabular}{|c|c|c|c|c|c|c|c|c|}
\hline \multirow[t]{2}{*}{ Protozoa group } & \multicolumn{2}{|c|}{ Ciliates } & \multicolumn{3}{|c|}{ Outflow rate } & \multicolumn{3}{|c|}{ Residence time } \\
\hline & Number & SD & A & B & SD & A & B & SD \\
\hline Entodinium sp. & 587.8 & 93.34 & 95.7 & 95.5 & 11.02 & 25.2 & 25.7 & 2.83 \\
\hline Polypl. multivesiculatum & 3.1 & 1.78 & 75.6 & 77.3 & 18.31 & 32.7 & 34.6 & 9.75 \\
\hline „other Diplodinia" & 12.4 & 10.72 & 95.6 & 91.6 & 30.61 & 27.4 & 30.6 & 10.55 \\
\hline Isotricha sp. & 2.0 & 0.41 & 177.2 & 171.6 & 38.32 & 13.8 & 15.0 & 3.28 \\
\hline Dasytricha ruminantium & 9.2 & 2.33 & 123.8 & 114.7 & 23.20 & 20.2 & 21.6 & 3.95 \\
\hline
\end{tabular}

in the case of Polyplastron multivesiculatum while the largest in the case of Isotricha sp. All the results are presented in Table 5.

\section{DISCUSSION}

The results obtained provide direct evidence for reduced concentration of ciliates from the genus Entodinium and Diplodinium in reticular digesta compared with rumen contents of sheep. The observed reduction can result from selective retention of ciliates in the rumen due to attachment of these organisms to particulate fractions of rumen contents and their sequestration between large particles of food forming a sort of filter on the way from the rumen to reticulum. A similar phenomenon was already observed in earlier investigations (Michałowski, 1990). Conversely no sequestration seems occur in reticulum as the reticular digesta is composed of the liquid phase and very small food particles (unpublished). Due to this no differences were observed between the concentration of ciliates in reticular content and omasal influent (Harmeyer and Michałowski, 1991).

In contrast to Entodinium and Diplodinium, the concentration of Isotricha sp. and Dasytricha ruminantium in the rumen and the reticular digesta were sametimes similar. Holotrichs, however, seem to belong to organisms of the liquid fraction of rumen contents. Moreover the cuticula of these ciliates is not very rigid as of entodiniomorphs and, especially, of large Diplodinium. Due to this the cells of Holotricha are very flexible and this property could make any passage of these ciliates through the filter mentioned above much easier. Noteworthy is also fact that these protozoa temporarily attach to the reticulum wall (Abe et al., 1981). Thus their detachment could raise the concentration in reticular digesta.

The apparent residence time of protozoa in the rumen varied from about 13 to over $36 \mathrm{~h}$. The residence time of Polyplastron multivesiculatum and "other Diplod- 
inia" in the both sheep and Entodinium in sheep „R", were similar while that of Entodinium in sheep "L" was something shorter as compared with the results obtained by Michałowski et al. (1986). The residence time, however, was calculated there on the basis of concentration of ciliates in the omasal effluent thus any sequestration and/or lysis some of protozoa within the omasum can not be precluded and such a possibility has been suggested by the authors. The residence time of the both "Holotricha sp" and Dasytricha ruminantium were by two time shorter than calculated by cited authors. These protozoa, however, are very mobile and due to this they could escape of the passage to the omasum. The lysis of holotrichs within the omasum can not be, also precluded. Thus this phenomenon needs experimental explanation.

The aim of this investigation was to verify a suggestion that the concentration of ciliates in reticular digesta could be suitable to calculate the outflow of protozoa down the omasum. The basis for this assumption was similar concentration of ciliates in reticular digesta and in omasal influent (Harmeyer and Michałowski, 1991). Unfortunately there did not exist any possibility for simultaneous collection of the digesta from the reticulum and omasum. Thus it is only possible to compare the obtained results with the data of other authors. The mean concentration of ciliates from the genus Diplodinium in reticulum equaled $43-52 \%$ of their density in the rumen. The respective values for Holotrich $a$ were $75-95 \%$. Similar differences were found between the concentration of holotrichs and large and medium entodiniomorphs in the ruminal and omasal digesta (Punia et al. 1992; Punia and Leibholz, 1994). Thus the cited findings suggest that outflow of Diplodinium and Holotricha could be calculated on the basis of their concentration in reticulum. The concentration of Entodinium in reticulum of sheep was by about 31-53\% lower than in the rumen. The concentration of small ciliates (presumably, mainly Entodinium) in the omasal digesta account only for $26-45 \%$ of the density in the rumen (Punia et al., 1992; Punia and Leibholz, 1994). This suggest a possibility of some overestimation when the concentration of Entodinium in the reticulum would be the basis for calculation of the outflow of these ciliates down the omasum. On the other hand, however, no differences were found between the concentration of ciliates in the reticular digesta and omasal influent (Harmeyer and Michałowski, 1991). In fact, these last data concern only to the total number of protozoa but Entodinium accounted there for over $90 \%$ of the total count. Thus further investigation are necessary to explain this discrepancy.

The calculated daily outflow of protozoa equaled $66-180 \%$ of their number in whole rumen contents per day. These values are much higher in comparison with the findings of Weller and Pilgrim (1974) who calculated the outflow of ciliates on the basis of their concentration in the liquid taken from the omasal canal. It should be emphasized, however, that the outflow of protozoa described by the mentioned authors seems to be exceptionally low. It was not confirmed by other investigators 
either by indirect or by more direct methods (Harrison et al., 1979; Steinhour et al., 1981; Michałowski et al., 1986; Punia et al. 1992; Punia and Leibholz, 1994). The outflow rate of ciliates in this experiment varied in high ranges in relation to the group of protozoa. The outflow of Polyplastron multivesiculatum and "other Diplodinia" was within the range calculated on the basis of concentration of ciliates in omasal effluent (Michałowski et al., 1986). The outflow rate, however, of Entodinium and especially Holotricha was faster. It is possible that these ciliates, having more delicate cuticlula, are more susceptible to disintegration in the omasum. Thus their inflow to and outflow from the omasum may not be equal. Such a possibility is suggested by low proportion of protozoal $\mathrm{N}$ in the microbial $\mathrm{N}$ leaving the omasum of the sheep (Michałowski, 1990). Protozoal N was calculated in that study on the basis of $\mathrm{N}$ content in single cells of ciliates and their number leaving the omasum. The obtained results are distinctly lower than those calculated from concentration of different markers or the amino acid profile (Harrison et al., 1979; Steinhour et al., 1982; Cockburn and Williams, 1984; Meyer et al., 1986) as well as on the basis of protozoa concentration in the omasal digesta (Punia et al., 1992).

The presented results and the data of other authors, cited above, seem to suggest that perhaps the concentration of ciliates in the reticulm could be the basis for calculation of the outflow of ciliates from the reticulo-rumen down the lower digestive tract. However, further investigations are necessary to confirm this hypothesis, and especially the experiments enabling simultaneous sampling of the reticular and omasal digesta from the same animals are necessary to confirm this hypothesis. A collection of numerous samples during each day of experiment seem to be also necessary to minimize any possibility of overestimation.

The concentration of ciliates in digesta taken from the reticulum at the contraction and resting phases were similar. This suggests that recording the motility of reticulum can be omitted in the proposed sampling technique. On the other hand, however, recording by the method described in this paper precludes any uptake of a sample of digesta from another compartment in the reticulo-rumen.

\section{REFERENCES}

Abe M., Iriki T., Tobe N., Shibui H., 1981. Sequestration of holotrich protozoa in the reticulo rumen of cattle. Appl. Environ. Microbiol. 41, 758-765

Cockburn J.E., Williams A.P., 1984. The simultaneous estimation of the amounts of protozoal, bacterial and dietary nitrogen entering the duodenum of steers. Brit. J. Nutr. 51,111-132

Dogiel V.A., 1927. Monographie der Familie Ophryoscolecidae. Arch. Protistenkd. 59, 1-288

Grain J., 1966. Étude cytologique de quelques ciliés holotrichs endocommensaux des ruminans et des équides. Protistologica 2, 5-141

Harmeyer J., Michałowski T., 1991. A technique for the collection of reticular effluent of sheep. J. Vet. Med., A 38,107-114 
Harrison D.G., Beever D.E., Osbourn D.F., 1979. The contribution of protozoa to the protein entering the duodenum of sheep. Brit. J. Nutr. 41, 521-534

John A., Ulyatt M., 1984. Measurement of protozoa using phosphatidyl choline and of bacteria, using nucleic acids, in the duodenal digesta of sheep fed chaffed lucerne hay (Medicago sativa L.) diets. J. Agric. Sci. Camb. 102, 33-44

Hydén S., 1961. The use of reference substances and measurement of flow in the alimentary tract. In: D. Lewis (Editor). Digestive Physiology and Nutrition of the Ruminant. Butterworths, London, pp. 35-47

Meyer J.H.F., Van der Walt S.I., Schwartz M.H., 1986. The influence of diet and protozoal numbers on the breakdown and synthesis of protein in the rumen of sheep. J. Anim. Sci. 62, 509-520

Michałowski T., 1975. Effect of different diets on the diurnal concentration of ciliate protozoa in the rumen of water buffalo. J. Agric. Sci., Camb. 85, 145-150

Michałowski T., 1990. The distribution of ciliates through the reticulo-rumen of sheep. Acta Protozool. 29, 213-220

Michałowski T., Harmeyer J., Breves G., 1986. The passage of protozoa from the reticulo-rumen through omasum of sheep. Brit. J. Nutr. 56, 625-634

Punia B. S., Leibholz J., 1994. Effect of intake of kikuyu (Pennisetum clandestinum) grass hay on the flow of protozoal nitrogen to the omasum of cattle. Anim. Feed Sci. Technol. 47, 77-87

Punia B.S., Leibholz J., Faichney G.J., 1992. Rate of production of protozoa in the rumen and the flow of protozoal nitrogen to the duodenum in sheep and cattle given pelleted diet of lucerne hay and barley. J. Agric. Sci., Camb. 118, 229-236

Ruszczyc Z., 1970. Methods of Animal Husbandrny Experiments (in Polnish). PWRiL, Warszawa

Steinhour W.D., Stokes M.R., Clark J.H., Rogers J.A., Davis C.L., Nelson D.R., 1982. Estimation of the proportion of non-ammonia-nitrogen reaching the lower gut of the ruminant derived from bacterial and protozoal nitrogen. Brit. J. Nutr. 48, 417-431

Weller R.A., Pilgrim A.F., 1974. Passage of protozoa and volatile fatty acids from the rumen of sheep and from continuous in vitro fermentation system. Brit. J. Nutr. 32, 341-351

Whitelaw F.G., Eadie J.M., Bruce L.A., Shand W.J., 1984. Microbial protein synthesis in cattle given roughage-concentrate and all-concentrate diets: the use of 2,6-diaminopimelic acid and 2-aminoethylphosphonic acid and ${ }^{35} \mathrm{~S}$ as markers. Brit. J. Nutr. 52, 249-260

\section{STRESZCZENIE}

\section{Prosta metoda do oznaczania wypływu pierwotniaków z czepcożwacza}

Dwie dorosłe owce, z trwałymi przetokami żwacza, użyto do badań nad intensywnością odpływu pierwotniaków z żwaczo-czepca do dalszych odcinków przewodu pokarmowego. Tempo odpływu pierwotniaków obliczano na podstawie ich gęstości w treści czepca i objętości płynu wypływającego z żwaczo-czepca. Stwierdzono, że gęstość pierwotniaków z rodzaju Entodinium i Diplodinium w czepcu była odpowiednio o 33-63 i 32-73 \% mniejsza niż w żwaczu. Liczebność Holotricha, w czepcu wahała się od 55,7 do 126,8 \% ich liczebności w żwaczu. Nie stwierdzono istotnej różnicy między gęstością populacji pierwotniaków w treści reticilum pobieranej w fazie spoczynku i podczas skurczu. Liczba orzęsków odpływających w ciągu doby do dalszych odcinków przewodu pokarmowego wahała się od 66 do $177 \%$ ich średniej liczby w żwaczu, a przeciętny czas ich przebywania w żwaczu wahał się od 13,8 , do 36,6 godzin, najdłuższej przebywały w żwaczu Diplodinia, najkrócej - Isotricha. W pracy opisano metodę pobierania prób treści czepca w fazie jego skurczu oraz w spoczynku. 